\title{
Cardiac tamponade, an unusual and fatal complication of esophagus dilatation for benign stenosis: a case report Wendela L Greven ${ }^{1}$, Nicole Kooij ${ }^{2}$, Herman M Peters ${ }^{2}$, Joost Kardux ${ }^{3}$ and Peter E Spronk*1,4,5
}

\author{
Address: ${ }^{1}$ Department of Intensive Care, Gelre Hospitals, Lukas site, Post office Box 9014, 7300 DS, Apeldoorn, The Netherlands, ${ }^{2}$ Department of \\ Pathology, Gelre Hospitals, Lukas site, Post office Box 9014, 7300 DS, Apeldoorn, The Netherlands, ${ }^{3}$ Department of Radiology, Gelre Hospitals, \\ Lukas site, Post office Box 9014, 7300 DS, Apeldoorn, The Netherlands, ${ }^{4}$ Department of Intensive Care Medicine, Academic Medical Center, Post \\ office box 22660, 1100 DD, Amsterdam, the Netherlands and ${ }^{5}$ HERMES critical care group, Amsterdam, the Netherlands \\ Email: Wendela L Greven - wendelagreven@hotmail.com; Nicole Kooij - n.kooij@gelre.nl; Herman M Peters - h.peters@gelre.nl; \\ Joost Kardux - j.kardux@gelre.nl; Peter E Spronk* - p.spronk@gelre.nl \\ * Corresponding author
}

Published: 24 December 2008

Cases Journal 2008, 1:419 doi:10.1186/1757-1626-1-419

This article is available from: http://www.casesjournal.com/content/l///419

(C) 2008 Greven et al; licensee BioMed Central Ltd.

This is an Open Access article distributed under the terms of the Creative Commons Attribution License (http://creativecommons.org/licenses/by/2.0), which permits unrestricted use, distribution, and reproduction in any medium, provided the original work is properly cited.
Received: 13 June 2008

Accepted: 24 December 2008

\begin{abstract}
Introduction: We present a patient with a fatal late esophago-pericardial fistula three months after dilatation for benign oesophagus stenosis

Case presentation: A 7I-year-old caucasian male with a known benign esophagus stenosis was referred to the ICU. On arrival an asystole developed which proved to be due to a large pericardial effusion. Pericardial fluids were drained, but the patients' condition worsened and he died due to multiple organ failure. Postmortum investigation revealed an esophago-pericardial fistula.
\end{abstract}

Conclusion: Causes of an acute tamponade should also be sought in semirecent events, such as manipulation to the oesophagus months before the acute critical illness.

\section{Introduction}

Cardiac tamponade can be caused by pericardial effusion and should always be considered whenever asystole is present. Causes of these effusions are often idiopathic, but include infections (viral, bacterial, tuberculosis), malignancy, iatrogenic causes, post-myocardial infarction or trauma, uremia, collagen vascular disorders, and radiotherapy $[1,2]$. In the developed world the most common cause of pericardial effusion is idiopathic pericarditis (80\%) [3], mostly caused by viral infections and its immunological response to it [4]. In idiopathic pericarditis, tamponade is rare $(14 \%)$, but it is more common (61\%) with other causes such as neoplastic effusion, tuberculosis and purulent effusion [4].
Fistula of the esophagus to the pericardial space have been described before and could cause infectious pericarditis with effusion. Among other causes of fistula formation are manipulation to the esophagus $[5,6]$. Esophagus dilatation is performed on a regular basis for benign stenotic conditions. We herein present a patient with a fatal late complication of this dilatation.

\section{Case Presentation}

A 71-year-old Caucasian male, was referred to our clinic because of high fever $\left(39.2^{\circ} \mathrm{C}\right)$. His medical history showed benign esophagus stenosis due to recurrent reflux disease and concomitant candida esophagitis. He did not take regular medication. On presentation the patient had 
fever and was feeling very ill, without any specific complaints. He did not smoke, drank only alcohol in weekends and had no significant family history. On physical examination the blood pressure was $80 / 40 \mathrm{~mm} \mathrm{Hg}$, pulse rate $115 \mathrm{bpm}$, respiratory rate $32 / \mathrm{min}$, length $178 \mathrm{~cm}$, weight $78 \mathrm{~kg}$. Further physical examination, including cardiac chest sounds, EKG, lung sounds and abdominal examination was normal. Laboratory results showed elevated $\mathrm{C}$ reactive protein $(252 \mathrm{mg} / \mathrm{l})$ and a leukocytosis $(16.9 / \mathrm{nL})$. A chest $\mathrm{x}$-ray and a regular urinary analysis did not show any infection. A sepsis of unknown origin was concluded and blood cultures were drawn. He was admitted to a nursing ward and treated with ceftriaxon $(2 \mathrm{gr}$ intravenous) and gentamycine (240 mg intravenous). The same night, his condition worsened and he was admitted to the intensive care unit (ICU), because of respiratory failure and hypotension. On physical examination at the ICU he still had high fever $\left(39.1^{\circ} \mathrm{C}\right)$, a breathing frequency of $40 /$ minute and a worsening hypotension (mean arterial pressure $51 \mathrm{Mm} \mathrm{Hg}$ ). It was not possible to hear cardiac sounds and his extremities were cold. He was intubated and after placement of a central line, the initial CVP was $7 \mathrm{~cm} \mathrm{H2O}$. Intravenous fluid replacement was started as well as inotropics (dopamine $4.5 \mu \mathrm{g} / \mathrm{kg} / \mathrm{min}$; norepinephrin 0.5 up to $2.3 \mu \mathrm{g} / \mathrm{kg} / \mathrm{min}$; milrinone 0.25 $\mu \mathrm{g} / \mathrm{kg} / \mathrm{min}$ ). The patients' condition worsened quickly and an aystole developed. Cardiopulmonary resuscitation (CPR) was started. An ultrasound of the heart showed a tamponade with pericardial effusion. Pericardial fluids were drained and his hemodynamic situation improved rapidly, although vasopressors could not be completely weaned. The patient improved at first, but within 12 hours his condition worsened again. A new ultrasound of the heart showed again pericardial effusion, in which a small catheter was placed to perform drainage. However, his clinical condition worsened further and he died a few hours later due to hemodynamic shock unresponsive to therapy.

Postmortum examination showed a fistula from the esophagus directly to the pericardium. A white liquid was used to confirm the fistular connection, i.e. within a few seconds it appeared from the esophageal origin in the pericardial space (figure 1). Post-mortem culture of the pericardial effusion showed candida species.

His family told that he had had complaints of unwell being and atypical thoracic pain since his last esophagoscopy with dilatation of the esophagus stenosis, three months before. Most likely he had been suffering a chronic (candida) mediastinitis since his last esophagus dilatation three months before ICU admission, which had been complicated by fistula formation to the pericardial space, resulting in a cardiac tamponade due to pericardial effusion.

\section{Discussion}

Fistula between the esophagus or stomach and pericardium or other sites of the heart (atrial, ventricular) have been described before. Predisposing factors to fistula formation are surgery to the esophagus, such as esophagectomy with retrosternal gastric tube reconstruction [5] and Nissen fundoplication [6]. Other predisposing factors to fistula formation are esophageal diverticula [7], neoplasmata [8-10], benign ulcers [11] and foreign bodies [12]. The mechanism could consist of a fistula from the esophagus to the mediastinum first, resulting in a chronic mediastinitis, resulting in fistula formation to the pericardium of the heart or other sites in the mediastinum, such as the diaphragma [13]. Our patient had suffered of chronic candida esophagitis for some months. Moreover a dilatation was performed to the esophagus, most likely causing a trauma. So our patient not only had a porte d'entrée, but he was also colonized with a pathogen, that could cause the mediastinitis and eventually fistula formation to the pericard, causing pericarditis.

In literature described pathogens causing a pericarditis due to fistula include Candida species [5,6], and streptoccus species $[7,10]$. Candida pericarditis is a rare surgical emergency, usually occurring in immunocompromised hosts, antibiotic-treated patients or after pericardiotomy [14]. Esophagopericardial fistula have a very high mortality, approximately $85 \%$ [11]. In candida pericarditis, pericardiocentesis, antifungal therapy, followed by operative drainage is the therapy of choice [14]. Herein early diagnosis and prompt treatment are most important [15] as is operative closure of the fistula [11]. In our patient, due to his septic state and the rapid worsening of his condition only pericardiocentesis could be performed, which was unfortunately not sufficient to stabilize his clinical status.

\section{Conclusion}

Esophagus-pericardial fistula have been described in varying predisposing conditions. This is the first case demonstrating cardiac tamponade due to fistula formation after esophagus dilatation for benign stenosis. This report shows that causes of an acute tamponade, should also be sought in semirecent events, such as manipulation to the oesophagus months before acute critical illness.

\section{Consent}

Written informed consent was obtained from the patient for publication of this case report and accompanying images. A copy of the written consent is available for review by the Editor-in-Chief of this journal.

\section{Competing interests}

The authors declare that they have no competing interests. 


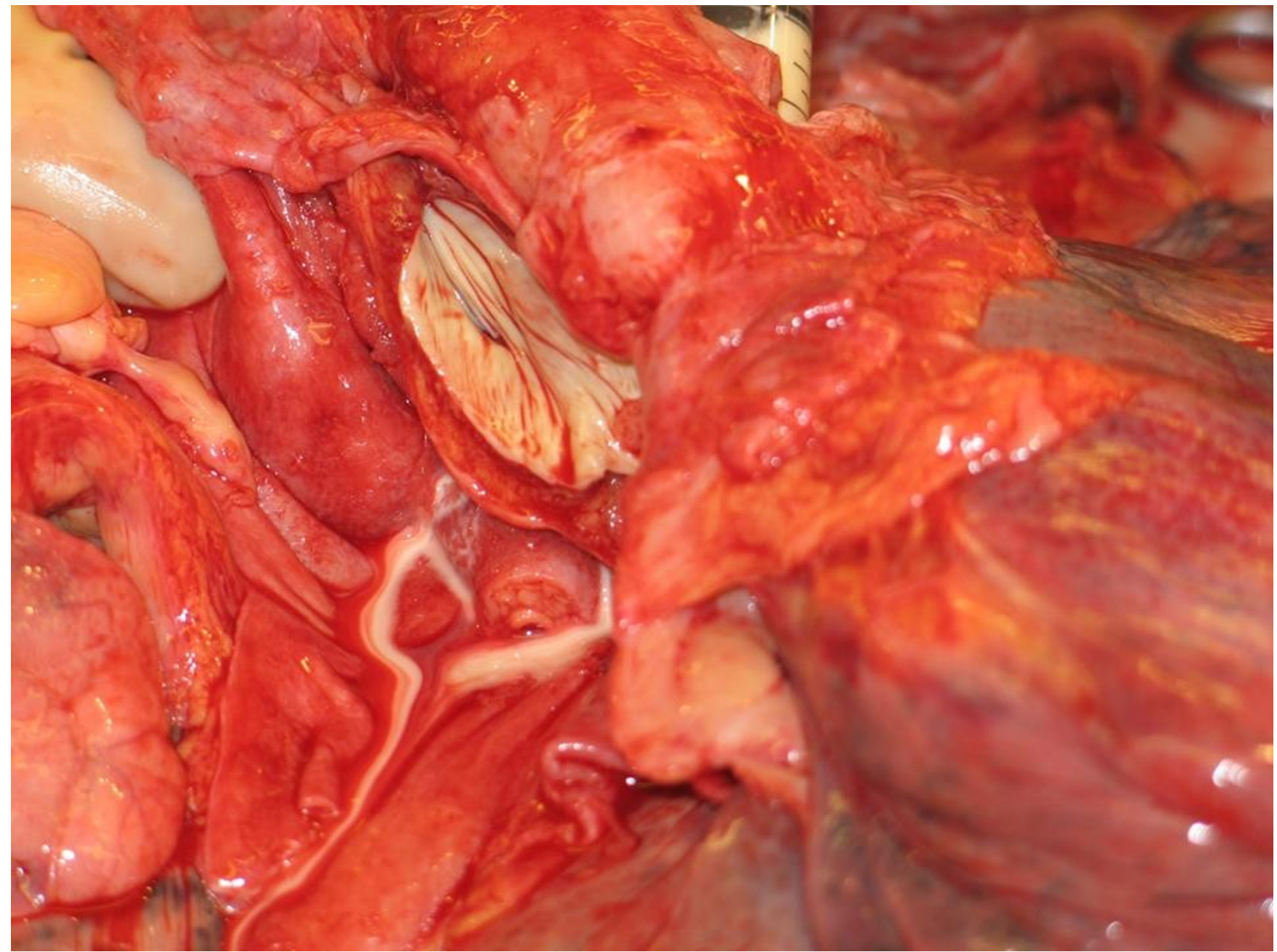

\section{Figure I}

A white liquid was used to confirm the fistular connection, i.e. within a few seconds it appeared from the esophageal origin in the pericardial space.

\section{Authors' contributions}

WG analyzed and interpreted the patient data. WG and PS were the major contributors in writing the manuscript. All authors read and approved the final manuscript.

\section{References}

I. Corey GR, Campbell PT, Van Trigt P, Kenney RT, O'Connor CM, Sheikh KH, Kisslo JA, Wall TC: Etiology of large pericardial effusions. Am J Med I993, 95(2):209-13.

2. Sagrista-Sauleda J, Merce J, Permanyer-Miralda G, Soler-Soler J: Clinical clues to the causes of large pericardial effusions. Am J Med 2000, I09(2):95-101.

3. Soler-Soler J, Permanyer-Miralda G, Sagristà-Sauleda J: A systematic diagnostic approach to primary acute pericardial disease. The Barcelona experience. Cardiol Clin 1990, 8(4):609-20.

4. Permanyer-Miralda G: Acute pericardial disease: approach to the aetiologic diagnosis. Heart 2004, 90(3):252-4.

5. Van Beek LM, Landman IJ, Verheught FW: A man with candida pyopneumopericarditis and cardiac tamponade in conjunction with gastric tube infection. Ned Tijdschr Geneeskd 2005, 149:2517-2i.
6. Farjah F, Komanapalli CB, Shen I, Sukumar MS: Gastropericardial fistula and candida kruzei pericaditis following Nissen fundoplication (gastropericardial fistula). Thorac Cardiovasc Surg 2005, 53:365-7.

7. Kabra R, Welk KF, Kernstine KH, Field FJ, Thompson BH, Vats HS, Weintraub NL: Bacterial pericarditis due to group $F$ streptococci as a complication of oesophagomediastinal fistula. Ann Thorac Surg 2005, 79:2। 32-4.

8. Luthi F, Groebli Y, Newton A, Kaeser P: Cardiac and pericardial fistulae associated with esophageal or gastric neoplasms: a literature review. Int Surg 2003, 88(4): I88-93.

9. Kaufman J, Thongsuwan N, Stern E, Karmy-Jones R: Esophagealpericardial fistula with purulent pericarditis secondary to esophageal carcinoma presenting with tamponade. Ann Thorac Surg 2003, 75(I):288-9.

10. Muto M, Ohtsu A, Boku N, Tajiri H, Yoshida S: Streptococcus milleri infection and pericardial abscess associated with esophageal carcinoma: report of two cases. Hepatogastroenterology 1999, 46(27): 1782-4.

II. Miller WL, Osborn MJ, Sinak LJ, Westbrook B: Pyopneumopericardium attributed to an esophagopericardial fistula: report of a survivor and review of the literature. Mayo Clin Proc 1991, 66(10): $104 \mid-5$. 
12. Pulatov AT, Kim LE, Rofiev RR: An esophageal foreign body in a child causing the development of an esophago-pericardial fistula and suppurative pericarditis. Khirurgiia (Mosk) 1992:100-2.

13. Hauters P, de Canniere L, Collard JM, Buysschaert M, Michel LA: Gastrodiaphragmatic fistula after transabdominal Nissen fundoplication. An unusual complication. J Clin Gastroenterol 1990, I2(3):313-5.

14. Rabinovici R, Szewczyk D, Ovadia P, Greenspan JR, Sivalingam JJ: Candida pericarditis: clinical profile and treatment. Ann Thorac Surg 1997, 63(4): 1200-4.

15. West $A B$, Nolan N, O'Briain DS: Benign peptic ulcers penetrating pericardium and heart: clinicopathological features and factors favoring survival. Gastroenterology 1988, 94(6): 1478-87.

Publish with Biomed Central and every scientist can read your work free of charge

"BioMed Central will be the most significant development for disseminating the results of biomedical research in our lifetime. "

Sir Paul Nurse, Cancer Research UK

Your research papers will be:

- available free of charge to the entire biomedical community

- peer reviewed and published immediately upon acceptance

- cited in PubMed and archived on PubMed Central

- yours - you keep the copyright

Submit your manuscript here:

http://www.biomedcentral.com/info/publishing_adv.asp 